\title{
Immunoregulation on Mice of Low Immunity and Effects on Five Kinds of Human Cancer Cells of Panax japonicus Polysaccharide
}

\author{
Zhang Jie, ${ }^{1}$ Li Chun-Yan, ${ }^{1,2}$ Li Jing-Ping, ${ }^{3}$ Guo Ren, ${ }^{1}$ \\ Wang Hui, ${ }^{4}$ Pan Juan, ${ }^{5}$ and Liu Sheng-Lan ${ }^{1}$ \\ ${ }^{1}$ Third Xiangya Hospital, Central South University, Changsha 410013, China \\ ${ }^{2}$ Changsha University, Changsha 410022, China \\ ${ }^{3}$ School of Pharmaceutical Science, Central South University, Changsha 410013, China \\ ${ }^{4}$ The Central Hospital of Taian, Taian 271000, China \\ ${ }^{5}$ Maternal and Child Health Hospital, Liuyang 410300, China
}

Correspondence should be addressed to Li Chun-Yan; bbc223@126.com

Received 25 December 2014; Revised 9 April 2015; Accepted 16 April 2015

Academic Editor: Jairo Kennup Bastos

Copyright (C) 2015 Zhang Jie et al. This is an open access article distributed under the Creative Commons Attribution License, which permits unrestricted use, distribution, and reproduction in any medium, provided the original work is properly cited.

\begin{abstract}
The goal of this study is to investigate the immunoregulative effects of Panax japonicus polysaccharide (PJPS) on mice of low immunity. An orthogonal experiment was designed to determine the best extraction process for PJPS. By the tests of macrophages swallow chicken red blood cells, Delayed-type hypersensitivity (DTH), and serum hemolysin value, we studied the immune adjustment ability of PJPS. MTT was employed to detect the effects of different concentrations of PJPS, respectively, in $24 \mathrm{~h}, 48 \mathrm{~h}$, and $72 \mathrm{~h}$ on five kinds of human cancer cells. The results show that the best extraction process for PJPS was as follows: ratio of solvent consumption to raw material 40 , extraction temperature $100^{\circ} \mathrm{C}$, re-extracted two times, each extraction time 4 hours. PJPS can significantly improve the immune function of mice processed by cyclophosphamide and PJPS did not work on the above five cancer cells.
\end{abstract}

\section{Introduction}

Rhizoma Panacis Japonici, a special resource of Tujia nation in Hunan Province, belongs to Araliaceae plant and its dry rootstalk could be used as medicine. It is warm, sweet, and bitter. In Chinese medicine, being a natural plant used as both medicine and food, it has both the nutrition effects of ginseng and can activate blood circulation to dissipate blood stasis [1]. Several studies have indicated its pharmacological effects on the central nervous system [2,3], digestive system [4], cardiovascular system $[5,6]$, immune system [7], inflammation [8-10], fatigue $[11,12]$, tumor $[13,14]$, and so on.

It contains various saponins, polysaccharides, and some active substances like amino acids, volatile oil [15], and so forth. Saponin is the most abundant material of chemical composition in the Rhizoma Panacis Japonici. At present, there are numerous studies concerning the chemical structure and pharmacological activity of saponins. However, the studies of Panax japonicus polysaccharide (PJPS) are limited. It may be partly due to the complex chemical structure and ambiguous mechanism of action. Ohtani et al. [16] reported that PJPS extracted from Rhizoma Panacis Japonici can activate the reticuloendothelial system, which suggests that PJPS can improve activity of macrophages in the reticuloendothelial system and play a role in immune regulation via this way. Other results suggest that the PJPS can promote immune organ weight index of immunosuppressed mice, significantly improve the spleen lymphocyte proliferation, promote serum IgM level following exposure to chicken red blood cells and QSH reaction, and promote natural killer's cells activity. It has better immune enhancement effect and recovers immune system of immunosuppressed mice [17]. 


\section{Experimental}

2.1. Extraction Process of PJPS. Firstly, single factor experiments were studied. Rhizoma Panacis Japonici powder, which has been sifted by 50 meshes, was extracted by hot water. The extraction rate of PJPS as index, the number of extractions, solvent ratio, extraction time, and extraction temperature were investigated as the single factors. Secondly, on the basis of single factor experiments, the orthogonal experiment was designed with the extraction rate of PJPS as index to optimize and determine the best extraction process. At last, validated experiment was made.

Selecting anhydrous glucose as the standard, this paper investigated the determination conditions and methodology of anthrone sulfuric acid method [18]. Consider

the extraction rate of PJPS (\%)

$$
\begin{aligned}
= & \frac{\text { the quality of PJPS extracted from Rhizoma Panacis Japonici }}{\text { the quality of PJPS of Rhizoma Panacis Japonici }} \\
& \times 100 \%
\end{aligned}
$$

2.2. Separations and Refining of PJPS. The aqueous extract, which was acquired according to the optimum extraction method of PJPS, was concentrated to a certain volume; then the concentrate was obtained. The concentrate was further precipitated by adding anhydrous ethanol to its concentration of $80 \%$ ethanol. It was refrigerated over $12 \mathrm{~h}$. The sedimentation was separated by being centrifuged for $15 \mathrm{~min}(5000 \mathrm{rpm})$. Then, the sedimentation was washed twice with appropriate amount of ethanol and was freezedried into constant weight. Through these progresses, the insoluble substance was crude PJPS.

Crude PJPS solution, which was made up at the mass concentration of $1 \%$, was added to $1.2 \%$ of papain solution (dynamic unit $400 \mu / \mathrm{mg}$ ). Under the optimum $\mathrm{pH}$ value 6.0 and the optimum enzymatic hydrolysis temperature $40^{\circ} \mathrm{C}$, enzymatic hydrolysis was reacted for $2 \mathrm{~h}$. Enzyme deactivation was done at $90^{\circ} \mathrm{C}$. This solution was centrifuged for $10 \mathrm{~min}(5000 \mathrm{rpm})$ to get rid of denatured protein, then the supernatant was obtained. The supernatant was precipitated for $12 \mathrm{~h}$ by the addition of ethanol to a final concentration of $80 \%(\mathrm{v} / \mathrm{v})$, and centrifuged for $15 \mathrm{~min}(5000 \mathrm{rpm})$. The sedimentation was washed twice with appropriate amount of ethanol and was freeze-dried into constant weight. Through these progresses, the insoluble substance was refined PJPS.

The concentration of crude PJPS was $1 \%$, and then $1.2 \%$ papain (dynamic unit $400 \mu / \mathrm{mg}$ ) was added. In its optimum $\mathrm{pH}$ value of 6.0 , the optimum enzymolysis temperature is $40^{\circ} \mathrm{C}$, enzymatic hydrolysis was reacted for $2 \mathrm{~h}$. Enzyme deactivation was done at $90^{\circ} \mathrm{C}$. This solution was centrifuged for $10 \mathrm{~min}(5000 \mathrm{rpm})$ to get rid of denatured protein, then the supernatant was obtained. The supernatant was precipitated for $12 \mathrm{~h}$ by the addition of ethanol to a final concentration of $80 \%(\mathrm{v} / \mathrm{v})$, and centrifuged for $15 \mathrm{~min}$ (5000 rpm). Sedimentation was washed twice with appropriate amount of ethanol and freeze-dried to constant weight. Through these progresses, the insoluble substance was refined PJPS.

\subsection{The Immune Regulating Effect of PJPS in Mice with Immunosuppression}

2.3.1. Phagocytic Function of Peritoneal Macrophage [19]. According to the different treatment, 90 Kunming mice were randomly divided into normal control group, cyclophosphamide (CY) model control group, $\mathrm{CY}+$ lentinan group (positive control group), and CY + low, CY + middle, and $\mathrm{CY}+$ high dosage group by weight and gender. Every group has 15 mice. The drug groups were pretreated intragastrically with $100 \mathrm{mg} / \mathrm{kg}, 200 \mathrm{mg} / \mathrm{kg}$, and $400 \mathrm{mg} / \mathrm{kg}$ PJPS. Positive control group was pretreated intragastrically with $150 \mathrm{mg} / \mathrm{kg}$ lentinan. Normal control group and cyclophosphamide model group were pretreated with saline at the same volume. All mice were separately administered once every day for 10 days for each group. From 7th day, cyclophosphamide was injected into enterocelia with $100 \mathrm{mg} / \mathrm{kg}$ for 3 days. At 11th day, mice were injected by $20 \%$ chicken red blood cell with $0.5 \mathrm{~mL} /$ only. Mice were executed after 35 minutes and cut open along the middle line of the abdominal wall skin, in which $2 \mathrm{~mL}$ physiological saline was injected by peritoneal injection. The experiment kneaded the mice's abdomen for 1 minute. Then abdominal lotion was sucked out, and then 1 drop of abdominal lotion was stilled on the glass slide and was observed by Wright-giemsa stain. Macrophages were counted 100 on each piece in the Oil immersion lens, and then the number of macrophages which swallowed chicken red blood cells and the number of chicken red blood cells which were swallowed were counted. The percentage of phagocytosis and phagocytic index was calculated. Consider

$$
\begin{gathered}
\text { the percentage of phagocytosis }=\frac{\text { the number of macrophages which swallow chicken red blood cells }}{100 \text { macrophages }} \times 100 \%, \\
\text { phagocytic index }=\frac{\text { the number of chicken red blood cells which are swallowed by macrophages }}{100 \text { macrophages }}
\end{gathered}
$$

$\times 100 \%$.

At the same time in the count, the degree of chicken red blood cells to be digested determines macrophage phagocytosis and digestion ability and also determines the standards of phagocytosis, which is usually divided into four levels: 
Class I: not be digested. Engulfed Chicken red blood cells are complete, cytoplasm is pale red or pale yellow with green, and cell nucleus is light purple.

Class II: mild digestion. Cytoplasm is chartreuse; cell nucleus is pycnosis and purplish blue.

Class III: serious digestion. Cytoplasm is dyed lightly and displays light grey.

Class IV: completely digestion. A physalides similar to the size of chicken red blood cell can be seen in macrophages.

2.3.2. Carbon Granular Clearance Ability. Group and administration were done like Section 2.3.1. On the 10th day after $2 \mathrm{~h}$ behind oral administration, each mouse was injected with India ink $0.1 \mathrm{~mL} / 10 \mathrm{~g}$ that was diluted 5 times with saline via coccygeal vein. After $5 \mathrm{~min}$ and $15 \mathrm{~min}$ behind the injection, $60 \mu \mathrm{L}$ of blood plasma, respectively, was taken from the orbital venous plexus with Vacuum blood tube which was wet by heparin solution in advance in EP tube containing $6 \mathrm{~mL} 0.1 \%$ sodium carbonate solution. The EP tube was shaken well. Then their OD values were measured at $680 \mathrm{~nm}$ wavelength with the reagent blank tube zero. At last, mice were dislocated and executed and the immunologic effects were measured by clearance rate $K$ of charcoal particles, phagocytic index $\alpha$, and thymus and spleen index.

2.3.3. Hemolysin Production Level. Group and administration were done like Section 2.3.1. From the fifth day, all groups were injected with $20 \%$ chicken red blood cell (CRBC) suspension of $0.2 \mathrm{~mL}$. After the last treatment, the mice were killed for serum (2000 rpm, $10 \mathrm{~min}$ ). Serum was diluted 500 times with saline water, to which $10 \%$ CRBC suspension of $0.5 \mathrm{~mL}$ and diluted guinea pig serum (complement) with 9 times saline water were added. By contrast, blank tube was added to saline $1 \mathrm{~mL}$ instead of mice serum liquid. Each tube in $37^{\circ} \mathrm{C}$ water bath is heated for $10 \mathrm{~min}$ and then is inserted in ice water bath for $10 \mathrm{~min}$ to terminate the reaction. After cooling, the tube was centrifuged at $2000 \mathrm{rpm}$ for $10 \mathrm{~min}$. Levels of serum hemolytic optical densities were measured in all groups. Results were analyzed by SPSS13.0 to compare differences between $\mathrm{OD}_{540}$ values of the groups.

2.3.4. Delayed-Type Hypersensitivity (DTH) Induced by 2,4Dinitrochlorobenzene (DNCB). Group and administration were like Section 2.3.1. From 4th day, cyclophosphamide was injected into enterocelia with $100 \mathrm{mg} / \mathrm{kg}$ once.

(1) Hypersensitive Response. On 5th day, barium sulfide liquid was applied to the abdomen for unhairing. $50 \mu \mathrm{L}$ of $5 \%$ DNCB fluid by pipetting gun was spread on the surface of depilatory parts to cause hypersensitive response.

(2) Checking Allergies. On 10th day, $10 \mu \mathrm{L}$ of $1 \%$ DNCB solution was applied to mice in order to attack both sides of the left ear. At the same time, both sides of the right ear were coated with the same amount of acetone sesame oil as comparison. The mice were killed after 24 hours. The right and left ears were cut, which were punched $8 \mathrm{~mm}$ round hole. The wafers were weighed by a scale.

(3) Results Analysis. Comparing the weight of the different groups mice's left auricular and right auricular, experimenter analyzed the average weight difference by SPSS13.0.

2.3.5. MTT Assay. Five kinds of cancer cells were chosen as the research object; they are human lung cancer cells HTB182, human colon cancer cells SW480, human kidney cancer cells HEK293, human nasopharyngeal carcinoma cell 5-8 F, and human liver cancer cell HepG2. Briefly, the cancer cells were plated in 96-well plate at a density of 1000-10000 cells/well in their respective medium. The cells were then incubated at $37^{\circ} \mathrm{C}$ in a $5 \% \mathrm{CO}_{2}$ environment for $24 \mathrm{~h}$. The experiment was divided into normal control group, negative control group, positive control group (DDP), and PJPS different dosage groups. Every group had 6 wells. After 24 hours, the normal control group and the negative control group were joined with the culture medium without drugs and the positive control group was joined with the culture medium containing $5 \sim 10 \mu \mathrm{g} / \mathrm{mL}$ DDP (cis-Dichlorodiammineplatinum(II); each cell had its cisplatin sensitivity and actual operation of each cell should choose a suitable concentration). The final concentration of PJPS different dosage groups was, respectively, $50 \mu \mathrm{g} / \mathrm{mL}, 100 \mu \mathrm{g} / \mathrm{mL}, 200 \mu \mathrm{g} / \mathrm{mL}, 400 \mu \mathrm{g} / \mathrm{mL}$, and $800 \mu \mathrm{g} / \mathrm{mL}$ and was, respectively, incubated at $37^{\circ} \mathrm{C}$ in a $5 \% \mathrm{CO}_{2}$ environment for $24 \mathrm{~h}, 48 \mathrm{~h}$, and $72 \mathrm{~h}$. After the designated time period, $20 \mu \mathrm{L}$ of 3-(4.5-dimethythiazol-2-yl)2,5-diphenyl tetrazolium bromide was added to each well and the plates were incubated at $37^{\circ} \mathrm{C}$ for additional $4 \mathrm{~h}$. The formazan crystals formed in the wells were dissolved in $150 \mu \mathrm{L}$ DMSO. The absorbance was measured at $490 \mathrm{~nm}$ using ELISA. The OD490 values were analyzed with SPSS13.0 statistical analysis and were compared with the difference.

\section{Results}

On the basis of the results of single factor experiments, designed $\mathrm{L}_{9}\left(3^{4}\right)$ orthogonal test of using the extraction rate of PJPS as index and using amount of solvent, extraction time, and extraction times as factors aimed to determine the rational extraction process. Analysis table of orthogonal experiment results is shown in Table 1 and variance analysis is shown in Table 2.

The range in Table 1 shows that the order of the influence factors on extraction rate of PJPS is $C$ (extraction temperature $)>A$ (solvent ratio) $>B$ (time). The results of analysis of variance in Table 2 showed that the solvent ratio and extraction temperature have a statistic significant influence on extraction rate of PJPS while extraction time on the influence of extraction rate of PJPS has no statistical significance. Through $K$ values of other factors and orthogonal experiment result, we can find that the best extraction technology of PJPS is $A_{3} B_{2} C_{3}$. The best extraction process for PJPS is demonstrated as follows: the solvent consumption was 40 times, the steeping time was $40 \mathrm{~min}$, and the extraction temperature was $100^{\circ} \mathrm{C}$, re-extracted at two times and each extraction time is 4 hours. 
TABLE 1: Results of orthogonal test for extraction technique of PJPS (\%).

\begin{tabular}{lccccc}
\hline Number & $A$ & $B$ & $C$ & $D$ & Extraction rate of PJPS (\%) \\
\hline 1 & 1 & 1 & 1 & 1 & 65.66 \\
2 & 1 & 2 & 2 & 2 & 73.68 \\
3 & 1 & 3 & 3 & 3 & 86.55 \\
4 & 2 & 1 & 2 & 3 & 75.36 \\
5 & 2 & 2 & 3 & 1 & 93.21 \\
6 & 2 & 3 & 1 & 2 & 68.23 \\
7 & 3 & 1 & 3 & 2 & 79.82 \\
8 & 3 & 2 & 1 & 3 & 79.97 \\
9 & 3 & 3 & 2 & 1 & 78.44 \\
$K 1$ & 75.297 & 79.613 & 71.287 & 79.910 & \\
$K 2$ & 78.933 & 82.287 & 75.480 & 80.627 & \\
$R 3$ & 85.063 & 4.393 & 92.527 & 1.870 & \\
\hline
\end{tabular}

TABLE 2: Analysis of variance.

\begin{tabular}{|c|c|c|c|c|c|}
\hline Factors & Sum of squares & DOF & $F$ & $F$ critical value & Significance \\
\hline$A$ & 146.190 & 2 & 27.371 & 19.000 & $*$ \\
\hline$B$ & 36.020 & 2 & 6.744 & 19.000 & \\
\hline C & 759.310 & 2 & 142.166 & 19.000 & $*$ \\
\hline Error & 5.341 & 2 & & & \\
\hline
\end{tabular}

Note. ${ }^{*} P<0.05$.

TABLE 3: Results of validation experiments.

\begin{tabular}{lccccc}
\hline Sample & 1 & 2 & 3 & Average & RSD (\%) \\
\hline $\begin{array}{l}\text { Extraction } \\
\text { rate (\%) }\end{array}$ & 97.99 & 98.35 & 98.73 & 98.36 & 0.38 \\
\hline
\end{tabular}

3.1. Validation Experiments. Table 3 shows that extraction rates of PJPS were $97.99 \%, 98.35 \%$, and $97.73 \%$, RSD was $0.38 \%$, and the average extraction rate reached $98.36 \%$. It shows that the extraction technology is stable and reliable in gaining high extraction rate.

3.2. Macrophage Cell Swallowed the Chicken Red Blood Cells. The morphological changes of macrophages during the process, in which microphages swallowed chicken erythrocytes, were observed by oil immersion lens. Figures 1, 2, and 3 are several typical cases. The macrophage phagocytic functions in the experiment of peritoneal macrophage phagocytizing chicken red blood cell are showed in Table 4.

In comparison with the control group, phagocytic rate and phagocytic index in CY group were significantly reduced. The results showed that CY could effectively decrease the mouse's peritoneal macrophage phagocytosis. Compared with CY group, phagocytic rate and phagocytic index in positive drug group were significantly enhanced $(P<$ $0.01)$. The phagocytic rate and phagocytic index in middle $\left(200 \mathrm{mg} \cdot \mathrm{kg}^{-1}\right)$ and high dose $\left(400 \mathrm{mg} \cdot \mathrm{kg}^{-1}\right)$ of PJPS groups were promoted greatly compared to the CY group $(P<0.05)$,
TABLE 4: The influence of PJPS on peritoneal macrophage phagocytizing chicken red blood cell.

\begin{tabular}{lcc}
\hline Groups & Phagocytic rate (\%) & Phagocytic index (\%) \\
\hline Normal group & $16.36 \pm 0.81$ & $19.64 \pm 0.93$ \\
$\begin{array}{l}\text { CY group } \\
\text { Lentinan group }\end{array}$ & $14.00 \pm 0.49^{* *} \pm 0.66^{* \# \#}$ & $10.31 \pm 0.44^{* *}$ \\
$\begin{array}{l}\text { PJPS low dosage } \\
\text { group }\end{array}$ & $9.07 \pm 0.50^{* * \Delta \triangle}$ & $10.52 \pm 0.64^{* * \# \#}$ \\
$\begin{array}{l}\text { PJPS middle dosage } \\
\text { group }\end{array}$ & $10.85 \pm 0.63^{* * \# \triangle \triangle}$ & $12.38 \pm 0.79^{* * * \Delta \triangle}$ \\
$\begin{array}{l}\text { PJPS high dosage } \\
\text { group }\end{array}$ & $13.76 \pm 0.74^{* * \# \#}$ & $15.92 \pm 0.74^{* * \# \#}$ \\
\hline
\end{tabular}

Note: values represent mean \pm SEM; $n=15$; significance as per Student's $t$ test compared with normal control group; ${ }^{*} P<0.05 ;{ }^{* *} P<0.01$, compared with CY group; ${ }^{\#} P<0.05$; ${ }^{\# \#} P<0.01$, compared with lentinan group; $\triangle^{\triangle} P<0.01$.

which indicated that the middle and high dose of PJPS could recover phagocytosis function of immunosuppression mice caused by CY. Lentinan group had no significant differences compared to the high dose group of PJPS.

3.3. Carbon Clearance Test. In comparison with the normal group, carbon clearance index $K$ and Phagocytic index $\alpha$ in CY group were significantly reduced. The results showed that CY could effectively decrease the mouse's peritoneal macrophage phagocytosis. In addition, high dose 


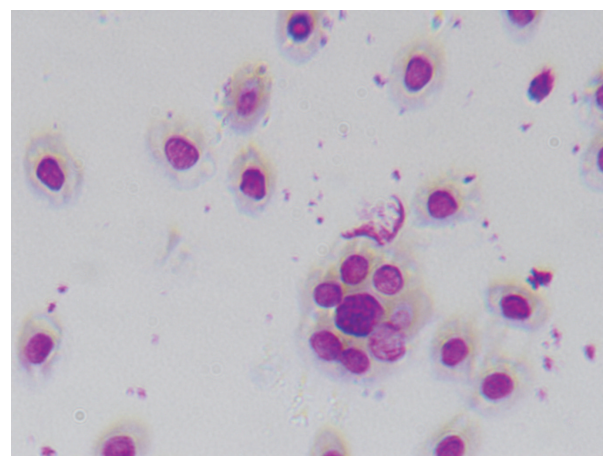

FIGURE 1: Macrophages adsorbed multiple chicken red blood cells.

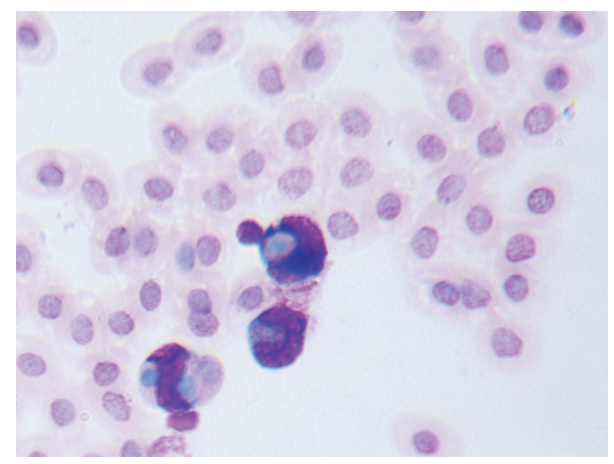

Figure 2: Macrophages swallowed multiple chicken red blood cells.

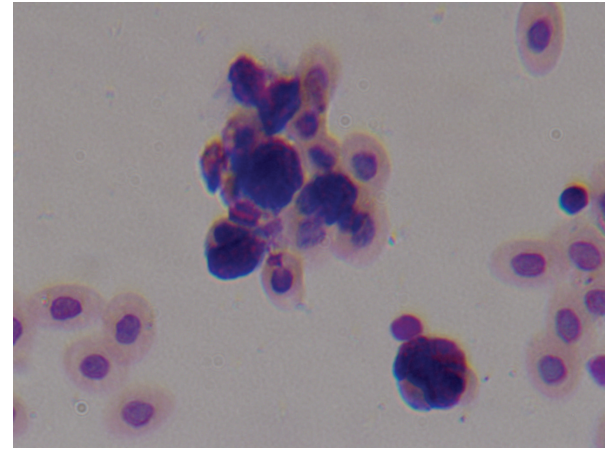

Figure 3: Macrophages adsorbed and swallowed multiple chicken red blood cells.

(400 mg. $\mathrm{kg}^{-1}$ ) of PJPS group had no significance compared with normal group, which indicated that PJPS could make the mouse's phagocytosis function return back to normal. Compared with CY group, carbon clearance index $K$ in positive drug group and high dose $\left(400 \mathrm{mg} \cdot \mathrm{kg}^{-1}\right)$ of PJPS groups were significantly enhanced $(P<0.05)$. Lentinan group $(P<0.01)$ and middle $\left(200 \mathrm{mg} \cdot \mathrm{kg}^{-1}\right)(P<0.05)$ and high dose $\left(400 \mathrm{mg} \cdot \mathrm{kg}^{-1}\right)$ PJPS groups $(P<0.01)$ were promoted greatly compared to the CY group, which indicated that lentinan group and the middle and high dose of PJPS could recover the phagocytosis function of immunosuppression mice caused by CY. The influences of
TABLE 5: The influence of PJPS on the carbon clearance index $K$ and Phagocytic index $\alpha$.

\begin{tabular}{lcc}
\hline Groups & $\begin{array}{c}\text { Carbon clearance } \\
\text { index } K^{1 / 2}\end{array}$ & Phagocytic index $\alpha$ \\
\hline Normal group & $0.146 \pm 0.026$ & $4.170 \pm 0.464$ \\
CY group & $0.059 \pm 0.013^{* *}$ & $2.071 \pm 0.334^{* *}$ \\
$\begin{array}{l}\text { Lentinan group } \\
\text { PJPS low dosage }\end{array}$ & $0.099 \pm 0.011^{* \#}$ & $3.264 \pm 0.219^{* \# \#}$ \\
$\begin{array}{l}\text { group } \\
\text { PJPS middle dosage }\end{array}$ & $0.084 \pm 0.013^{* *}$ & $2.817 \pm 0.306^{* *}$ \\
$\begin{array}{l}\text { group } \\
\text { PJPS high dosage } \\
\text { group }\end{array}$ & $0.096 \pm 0.006^{*}$ & $3.111 \pm 0.145^{* \#}$ \\
\hline
\end{tabular}

Note: values represent mean \pm SEM; $n=15$; significance as per Student's $t$ test compared with normal control group; ${ }^{*} P<0.05 ;{ }^{* *} P<0.01$, compared with $C Y$ group; ${ }^{\#} P<0.05 ;{ }^{\# \#} P<0.01$.

PJPS on the carbon clearance index $K^{1 / 2}$ and Phagocytic index $\alpha$ were showed in the Table 5 .

3.4. Delayed-Type Hypersensitivity (DTH) Induced by DNCB. In comparison with the normal group, auricle swelling degree in CY group and all dosage groups of PJPS were significantly enhanced. Compared with CY group, lentinan group has statistical significance $(P<0.01)$. In comparison with the normal group, the spleen index and thymus index were decreased significantly in CY group $(P<0.01)$. The influences of PJPS on the auricle swelling degree and visceral index were showed in the Table 6 . It showed that the immune suppression model that were induced via intraperitoneal injection of CY was established successfully. Compared with CY group, the spleen index in lentinan group and PJPS high dosage group were increased significantly $(P<0.05)$. The thymus index in both lentinan group $(P<0.01)$ and high dose group of PJPS $(P<0.05)$ was increased significantly compared to the CY group. Lentinan group had no significant differences compared to the high dose group of PJPS.

3.5. Hemolysin Production Level. By comparing the difference of each $\mathrm{OD}_{540}$ values in Table 7 , it can be found that $\mathrm{OD}_{540}$ values of groups were significantly lower than 
TABLE 6: The influence of PJPS on the auricle swelling degree and visceral index.

\begin{tabular}{lccc}
\hline Groups & Auricle swelling degree $(\mathrm{mg})$ & Thymus index $(\mathrm{mg} / \mathrm{g})$ & Spleen index $(\mathrm{mg} / \mathrm{g})$ \\
\hline Normal group & $3.08 \pm 0.47$ & $3.20 \pm 0.21$ & $6.04 \pm 0.44$ \\
CY group & $5.31 \pm 0.66^{* *}$ & $1.77 \pm 0.13^{* *}$ & $3.67 \pm 0.35^{* *}$ \\
Lentinan group & $3.08 \pm 0.42^{\# \#}$ & $2.54 \pm 0.11^{* * \# \#}$ & $5.15 \pm 0.34^{* \# \#}$ \\
PJPS low dosage group & $5.07 \pm 0.47^{* \Delta}$ & $2.06 \pm 0.23^{* * \Delta}$ & $3.86 \pm 0.38^{* * \Delta}$ \\
PJPS middle dosage group & $4.62 \pm 0.46^{* \triangle}$ & $2.17 \pm 0.18^{* *}$ & $4.09 \pm 0.36^{* *}$ \\
PJPS high dosage group & $4.46 \pm 0.66^{* \triangle}$ & $2.28 \pm 0.15^{* * \#}$ & $4.72 \pm 0.31^{* * \#}$ \\
\hline
\end{tabular}

Note: values represent mean $\pm \mathrm{SEM} ; n=15$; significance as per Student's $t$-test compared with normal control group; ${ }^{*} P<0.05$; ${ }^{* *} P<0.01$, compared with CY group; ${ }^{\#} P<0.05 ;{ }^{\# \#} P<0.01$, compared with lentinan group; ${ }^{\triangle} P<0.05$.

TABLE 7: The influence of PJPS on the $\mathrm{OD}_{540}$ value.

\begin{tabular}{lc}
\hline Groups & $\mathrm{OD}_{540}$ value \\
\hline Normal group & $0.108 \pm 0.001$ \\
CY group & $0.090 \pm 0.001^{* *}$ \\
Lentinan group & $0.099 \pm 0.003^{* * \#}$ \\
PJPS low dosage group & $0.098 \pm 0.003^{* * \#}$ \\
PJPS middle dosage group & $0.098 \pm 0.001^{* \# \#}$ \\
PJPS high dosage group & $0.103 \pm 0.001^{* \# \#}$ \\
\hline
\end{tabular}

Note: values represent mean \pm SEM; $n=15$; significance as per Student's $t$ test compared with normal control group; ${ }^{*} P<0.05 ;{ }^{* *} P<0.01$, compared with CY group; ${ }^{\# \#} P<0.01$, compared with lentinan group; ${ }^{\triangle} P<0.05$.

normal control group. CY group, Lentinan group, low dose group, and middle dose group compared with normal control group also had extremely significant difference $(P<0.01)$. Compared with $\mathrm{CY}$ group, $\mathrm{OD}_{540}$ values of PJPS different dosage groups were significantly higher than the CY group $(P<0.01)$, and with the increase of the dose of PJPS, $\mathrm{OD}_{540}$ values had a tendency to increase but had no statistical difference between PJPS different dosage groups. $\mathrm{OD}_{540}$ value of the high dose group was obviously higher than that of lentinan group $(P<0.05)$.

3.6. The Influence of PJPS on Proliferation of the Five Kinds of Human Cancer Cells in Tables 8, 9, 10, 11, and 12. The results showed that the OD value of DDP group in $24 \mathrm{~h}, 48 \mathrm{~h}$, and $72 \mathrm{~h}$ was lower than that of negative control group $(P<0.05)$, but all different doses of PJPS groups have no significant differences compared with negative control group. The result showed that PJPS had no obvious proliferation inhibition for five kinds of cancer cells.

\section{Discussions}

The orthogonal test was used to optimize the extraction conditions of polysaccharides from the rhizomes of Panax japonicus and elevate the extraction rate of PJPS. In the result, the best extraction process of PJPS is demonstrated as follows: the solvent consumption was 40 times, the steeping time was $40 \mathrm{~min}$, the extraction temperature was $100^{\circ} \mathrm{C}$, re-extraction at two times and each extraction time is 4 hours. All of PJPS were heteropolysaccharide, and polysaccharides with different ethanol concentration consist of different components. Polysaccharides contain pyranose ring, and the sugar composition analysis showed that PJPS are composed of arabinose, glucose, and galactose and the content of arabinose increased with the increasing of ethanol concentration [20, 21]. In activity analysis, polysaccharides with different ethanol concentration display different levels in activity, and polysaccharides with higher ethanol concentration have stronger recovery effect on DNA impaired [22].

As is well known, chemotherapy treatments for malignant tumour have strong adverse reactions; meanwhile myelosuppression and immunosuppression are especially severe and common. These toxic and side effects cause numerous patients to get infected and die of serious infectious diseases [23]. Polysaccharides have activity in regulation of body's immunity, which draw the attentions of domestic and international scholars, and some polysaccharides or extracts mainly containing polysaccharides have been further taken to clinical assessment in humans, such as polysaccharides from mushrooms. At present, the anticancer properties of polysaccharides have been shown to be primarily mediated via three approaches of direct cytotoxicity, immunoenhancement, and synergistic effects in combination with anticancer drugs. Meanwhile, the synergistic effects are known to be mediated by enhancing the sensitivity of tumour and elevating immune response to treatments [24]. Our experiments indicate that PJPS have effects on resisting immunosuppression caused by CY, such as improving macrophage phagocytosis and boosting the level of IgM in plasma. Some researches indicated that PJPS have the haematopoietic effect, repair impaired DNA, and have antioxidant activities [20, 22, 23, 25, 26]. Even though MTT assay indicated that PJPS do not have directly obvious effects on proliferation of lung cancer cells HTB182, colon cancer cells SW480, kidney cancer cells HEK293, nasopharyngeal carcinoma cella (NPC) 5-8 F, and human liver cancer cells HepG2, we can utilize haematopoietic effect and immunoenhancement of PJPS to resist myelosuppression and immunosuppression of chemotherapy; in other words, we can use PJPS in combination with anticancer drugs in clinic. Through this way, the risk of infection and myelosuppression may be decreased, as well as adverse effects, psychological and economical decline of using antibiotics; consequently PJPS in combination with chemotherapy may reduce mortality of cancer patients. However, this hypothesis needs to be proved by more studies. The mechanisms of PJPS 
TABLE 8: The influence of PJPS on human nasopharyngeal carcinoma cell 5-8F proliferation in different time.

\begin{tabular}{|c|c|c|c|c|}
\hline Groups & $\begin{array}{l}\text { Drug concentration } \\
(\mu \mathrm{g} / \mathrm{mL})\end{array}$ & $\begin{array}{c}24 \mathrm{~h} \\
\mathrm{OD}_{490} \text { value }\end{array}$ & $\begin{array}{c}48 \mathrm{~h} \\
\mathrm{OD}_{490} \text { value }\end{array}$ & $\begin{array}{c}72 \mathrm{~h} \\
\mathrm{OD}_{490} \text { value }\end{array}$ \\
\hline Negative group & - & $0.494 \pm 0.019$ & $0.598 \pm 0.016$ & $0.675 \pm 0.017$ \\
\hline \multirow{5}{*}{ Different dosage groups of PJPS } & 50 & $0.478 \pm 0.017$ & $0.580 \pm 0.020$ & $0.694 \pm 0.013$ \\
\hline & 100 & $0.492 \pm 0.018$ & $0.575 \pm 0.018$ & $0.676 \pm 0.013$ \\
\hline & 200 & $0.504 \pm 0.024$ & $0.584 \pm 0.012$ & $0.680 \pm 0.018$ \\
\hline & 400 & $0.508 \pm 0.025$ & $0.590 \pm 0.021$ & $0.683 \pm 0.010$ \\
\hline & 800 & $0.484 \pm 0.035$ & $0.597 \pm 0.019$ & $0.687 \pm 0.018$ \\
\hline DDP group & 5 & $0.401 \pm 0.016^{* *}$ & $0.404 \pm 0.023^{* *}$ & $0.325 \pm 0.027^{* *}$ \\
\hline
\end{tabular}

Note: values represent mean $\pm \mathrm{SEM} ; n=6$; significance as per Student's $t$-test compared with negative group; ${ }^{* *} P<0.01$.

TABLE 9: The influence of PJPS on lung cancer cells HTB182 proliferation in different time.

\begin{tabular}{lcccc}
\hline Groups & $\begin{array}{c}\text { Drug concentration } \\
(\mu \mathrm{g} / \mathrm{mL})\end{array}$ & $\begin{array}{c}24 \mathrm{~h} \\
\mathrm{OD}_{490} \text { values }\end{array}$ & OD $_{490}$ values $^{72 \mathrm{~h}}$ & $\mathrm{OD}_{490}$ values \\
\hline Negative group & - & $0.474 \pm 0.015$ & $0.536 \pm 0.015$ & $0.590 \pm 0.014$ \\
\hline & 50 & $0.496 \pm 0.018$ & $0.522 \pm 0.018$ & $0.594 \pm 0.015$ \\
Different dosage groups of PJPS & 100 & $0.482 \pm 0.016$ & $0.513 \pm 0.013$ & $0.589 \pm 0.015$ \\
& 200 & $0.500 \pm 0.015$ & $0.510 \pm 0.015$ & $0.611 \pm 0.021$ \\
& 400 & $0.484 \pm 0.011$ & $0.516 \pm 0.019$ & $0.601 \pm 0.014$ \\
DDP group & 800 & $0.495 \pm 0.011$ & $0.514 \pm 0.018$ & $0.584 \pm 0.024$ \\
\hline
\end{tabular}

Note: values represent mean \pm SEM; $n=6$; significance as per Student's $t$-test compared with negative group; ${ }^{* *} P<0.01$.

TABLE 10: The influence of PJPS on kidney cancer cells HEK293 proliferation in different time.

\begin{tabular}{|c|c|c|c|c|}
\hline Groups & $\begin{array}{c}\text { Drug concentration } \\
(\mu \mathrm{g} / \mathrm{mL})\end{array}$ & $\begin{array}{c}24 \mathrm{~h} \\
\mathrm{OD}_{490} \text { values }\end{array}$ & $\begin{array}{c}48 \mathrm{~h} \\
\mathrm{OD}_{490} \text { values }\end{array}$ & $\begin{array}{c}72 \mathrm{~h} \\
\mathrm{OD}_{490} \text { values }\end{array}$ \\
\hline Negative group & - & $0.376 \pm 0.021$ & $0.543 \pm 0.018$ & $0.662 \pm 0.012$ \\
\hline \multirow{5}{*}{ Different dosage groups of PJPS } & 50 & $0.402 \pm 0.015$ & $0.581 \pm 0.009$ & $0.666 \pm 0.011$ \\
\hline & 100 & $0.403 \pm 0.011$ & $0.592 \pm 0.012$ & $0.662 \pm 0.015$ \\
\hline & 200 & $0.375 \pm 0.016$ & $0.594 \pm 0.017$ & $0.669 \pm 0.014$ \\
\hline & 400 & $0.399 \pm 0.013$ & $0.595 \pm 0.014$ & $0.664 \pm 0.007$ \\
\hline & 800 & $0.377 \pm 0.011$ & $0.588 \pm 0.013$ & $0.662 \pm 0.011$ \\
\hline DDP group & 10 & $0.266 \pm 0.016^{* *}$ & $0.363 \pm 0.019^{* *}$ & $0.438 \pm 0.007^{* *}$ \\
\hline
\end{tabular}

Note: values represent mean \pm SEM; $n=6$; significance as per Student's $t$-test compared with negative group; ${ }^{* *} P<0.01$.

TABLE 11: The influence of PJPS on colon cancer cells SW480 proliferation in different time.

\begin{tabular}{lcccc}
\hline Groups & $\begin{array}{c}\text { Drug concentration } \\
(\mu \mathrm{g} / \mathrm{mL})\end{array}$ & $\begin{array}{c}24 \mathrm{~h} \\
\mathrm{OD}_{490} \text { values }\end{array}$ & OD $_{490}$ values $^{72 \mathrm{~h}}$ & $\mathrm{OD}_{490}$ values \\
\hline Negative group & - & $0.494 \pm 0.030$ & $0.490 \pm 0.019$ & $0.601 \pm 0.013$ \\
\hline & 50 & $0.440 \pm 0.020$ & $0.491 \pm 0.011$ & $0.600 \pm 0.011$ \\
Different dosage groups of PJPS & 100 & $0.418 \pm 0.017$ & $0.500 \pm 0.01$ & $0.599 \pm 0.009$ \\
& 200 & $0.431 \pm 0.023$ & $0.496 \pm 0.01$ & $0.595 \pm 0.011$ \\
& 400 & $0.436 \pm 0.033$ & $0.497 \pm 0.014$ & $0.599 \pm 0.013$ \\
DDP Value & 800 & $0.428 \pm 0.037$ & $0.495 \pm 0.011$ & $0.610 \pm 0.012$ \\
\hline
\end{tabular}

Note: values represent mean \pm SEM; $n=6$; significance as per Student's $t$-test compared with negative group; ${ }^{* *} P<0.01$. 
TABLE 12: The influence of PJPS on human liver cancer cells HepG2 proliferation in different time.

\begin{tabular}{lcccc}
\hline Groups & $\begin{array}{c}\text { Drug concentration } \\
(\mu \mathrm{g} / \mathrm{mL})\end{array}$ & $\begin{array}{c}24 \mathrm{~h} \\
\mathrm{OD}_{490} \text { values }\end{array}$ & $\mathrm{OD}_{490}$ values $^{72 \mathrm{~h}}$ & $\mathrm{OD}_{490}$ values \\
\hline Negative group & - & $0.440 \pm 0.023$ & $0.588 \pm 0.017$ & $0.689 \pm 0.022$ \\
\hline & 50 & $0.473 \pm 0.019$ & $0.608 \pm 0.019$ & $0.678 \pm 0.022$ \\
Different dosage groups of PJPS & 100 & $0.471 \pm 0.017$ & $0.601 \pm 0.019$ & $0.702 \pm 0.023$ \\
& 200 & $0.461 \pm 0.028$ & $0.613 \pm 0.020$ & $0.689 \pm 0.026$ \\
& 400 & $0.488 \pm 0.021$ & $0.605 \pm 0.013$ & $0.685 \pm 0.017$ \\
DDP Group & 800 & $0.385 \pm 0.015$ & $0.564 \pm 0.015$ & $0.698 \pm 0.023$ \\
\hline
\end{tabular}

Note: values represent mean $\pm \mathrm{SEM} ; n=6$; significance as per Student's $t$-test compared with negative group; ${ }^{* *} P<0.01$.

resisting myelosuppression and immunosuppression are also supposed to be further confirmed.

\section{Conclusion}

PJPS can significantly improve the immune function of mice processed by cyclophosphamide.

\section{Conflict of Interests}

The authors declare that there is no conflict of interests regarding the publication of this paper.

\section{Acknowledgment}

The authors are grateful to the school of pharmaceutical sciences of central south university, for providing research facilities and encouragement.

\section{References}

[1] Z. X. Du, Pharmaceutical Botany, People's Medical Publishing House, 2009.

[2] P. Wang, "Study on the anti-inflammatory and analgesic effect of Panax japonicus," Journal of Sichuan of Traditional Chinese Medicine, vol. 25, no. 12, pp. 17-19, 2007.

[3] D. J. Wen, C. L. Zhang, G. D. Chen, X. G. Dong, and B. J. Xiao, "Study on the analgesic effects of total Panax japonicus Saponins," Lishizhen Medicine and Materia Medica Research, vol. 19, no. 8, pp. 1983-1984, 2008.

[4] F. Borrelli and A. A. Izzo, "The plant kingdom as a source of anti-ulcer remedies," Phytotherapy Research, vol. 14, no. 8, pp. 581-591, 2000.

[5] J. Yuan, "The protective of panax japonicus saponins on myocardial ischemia reperfusion injury in dogs," Journal of Medicine and Pharmacy of Chinese Minorities, vol. 3, pp. 48-50, 2008.

[6] D. C. Xiang, "Influence of Panax japonicus on rats which suffered from limb ischemia reperfusion," Chinese Journal of Clinical Rational Drug Use, vol. 3, no. 11, pp. 1-2, 2010.

[7] J. Min and M. Z. Ao, "Effect of total saponins of Panax japonicus on immunological function," Lishizhen Medicine and Materia Medica Research, vol. 18, no. 11, pp. 2784-2785, 2007.
[8] D. Yuan, Y. Y. Dun, and C. C. Zhang, "Inhibitory effect of total saponins of Panax japonicus on the proliferation of synoviocytes in collagen-induced arthritis rats," Lishizhen Medicine and Materia Medica Research, vol. 19, no. 8, pp. 1882-1883, 2008.

[9] J. Min, "Anti-inflammatory effect of total saponins of Panax japonicus," Journal of Xiangning University, vol. 23, no. 6, pp. 464-467, 2009.

[10] Z. F. Wang, Q. L. Tan, and H. Zhang, "Experimental studies on the mechanism of compound Japanese Ginseng pill in treatment of rheumatoid arthritis," Lishizhen Medicine and Materia Medica Research, vol. 20, no. 7, pp. 1611-1613, 2009.

[11] L. N. Qian, P. Chen, X. L. Li, and Y. Y. Xiao, "Study on the antifatigue function of total saponins from Panax japonicas," Chinese Journal of Hospital Pharmacy, vol. 28, no. 15, pp. 12381240, 2008.

[12] H. Liu, "Experimental research on the antifatigue effect of Panax Japonicus," Journal of Hubei Institute for Nationalities (Medical Edition), vol. 18, no. 3, pp. 4-6, 2001.

[13] G. F. Ni and Zhejiang, "Experimental study on anti-tumor activity of different extracts from Panax japonicus in vitro," Journal of Traditional Chinese Medicine, vol. 42, no. 4, pp. 230231, 2007.

[14] D. Yuan, R. Zuo, and C. H. Zhang, "Effects of total saponins of Panax japonicas on human leukemic HL-60 cells," Journal of Chinese Integrative Medicine, vol. 5, no. 5, pp. 570-572, 2007.

[15] Y. L. N. Ou, D. W. Xiang, X. Wu, and D. X. Xiang, "The research progress for chemical components and pharmacological activities of Panax japonicas," Chinese Herbal Medicines, vol. 41, no. 6, pp. 1023-1027, 2010.

[16] K. Ohtani, S. Hatono, K. Mizutani, R. Kasai, and O. Tanaka, "Reticuloendothelial system-activating polysaccharides from rhizomes of Panax japonicus. I. Tochibanan-A and -B," Chemical and Pharmaceutical Bulletin, vol. 37, no. 10, pp. 2587-2591, 1989.

[17] C.-C. Zhang, H.-X. Zhao, M.-J. Jiang et al., "Effects of polysaccharides isolated from Panax japonicus on immunosuppression mice," Journal of Chinese Medicinal Materials, vol. 34, no. 1, pp. 91-94, 2011.

[18] J. Zhang, C. Y. Li, J. P. Li, J. Pan, and D. X. Xiang, "Determination of polysaccharide in rhizome of Panax japonicus by anthrone sulfuric acid and phenol sulfuric method," Central South Pharmacy, vol. 10, no. 6, pp. 421-424, 2012.

[19] Q. Chen, Research Methods in Pharmacology of Chinese Materia Medica, People's Medical Publishing House, 2011.

[20] R. Wang, P. Chen, F. Jia, J. Tang, and F. Ma, "Optimization of polysaccharides from Panax japonicus C.A. Meyer by RSM 
and its anti-oxidant activity," International Journal of Biological Macromolecules, vol. 50, no. 2, pp. 331-336, 2012.

[21] B. Xu, Study on the Composition and Activity of Polysaccharides from Panax japonicus C.A. Meyer, Wuhan Polytechnic University, Wuhan, China, 2009.

[22] X. Yang, R. F. Wang, S. P. Zhang et al., "Polysaccharides from Panax japonicus C.A. Meyer and their antioxidant activities," Carbohydrate Polymers, vol. 101, no. 1, pp. 386-391, 2014.

[23] S. Salva, G. Marranzino, J. Villena, G. Agüero, and S. Alvarez, "Probiotic Lactobacillus strains protect against myelosuppression and immunosuppression in cyclophosphamide-treated mice," International Immunopharmacology, vol. 22, no. 1, pp. 209-221, 2014.

[24] A. Zong, H. Cao, and F. Wang, "Anticancer polysaccharides from natural resources: a review of recent research," Carbohydrate Polymers, vol. 90, no. 4, pp. 1395-1410, 2012.

[25] R. Wang, P. Chen, F. Jia, J. Tang, F. Ma, and B. Xu, "Characterization and antioxidant activities of polysaccharides from Panax japonicus C.A. Meyer," Carbohydrate Polymers, vol. 88, no. 4, pp. 1402-1406, 2012.

[26] H. Zhang, H. F. Wang, Y. Liu et al., "The haematopoietic effect of Panax japonicus on blood deficiency model mice," Journal of Ethnopharmacology, vol. 154, no. 3, pp. 818-824, 2014. 


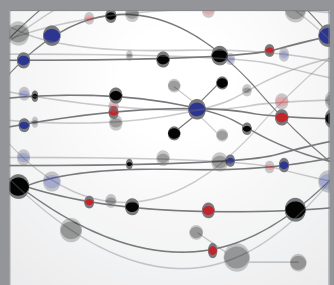

The Scientific World Journal
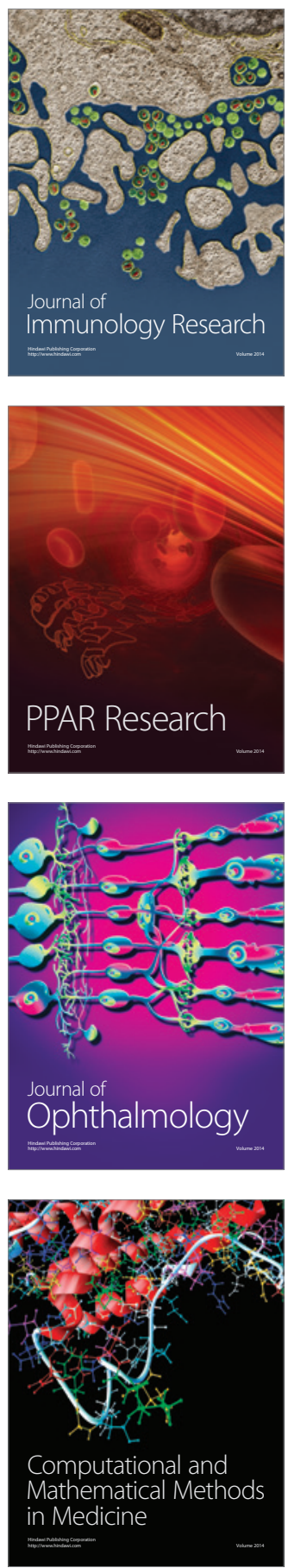

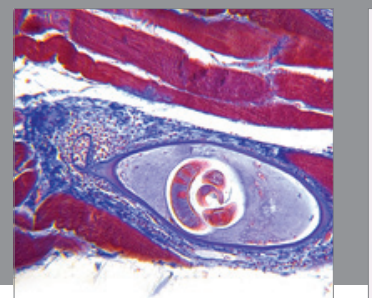

Gastroenterology

Research and Practice
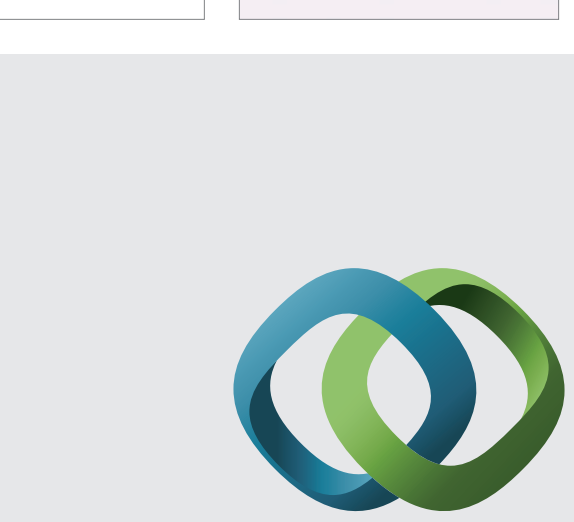

\section{Hindawi}

Submit your manuscripts at

http://www.hindawi.com
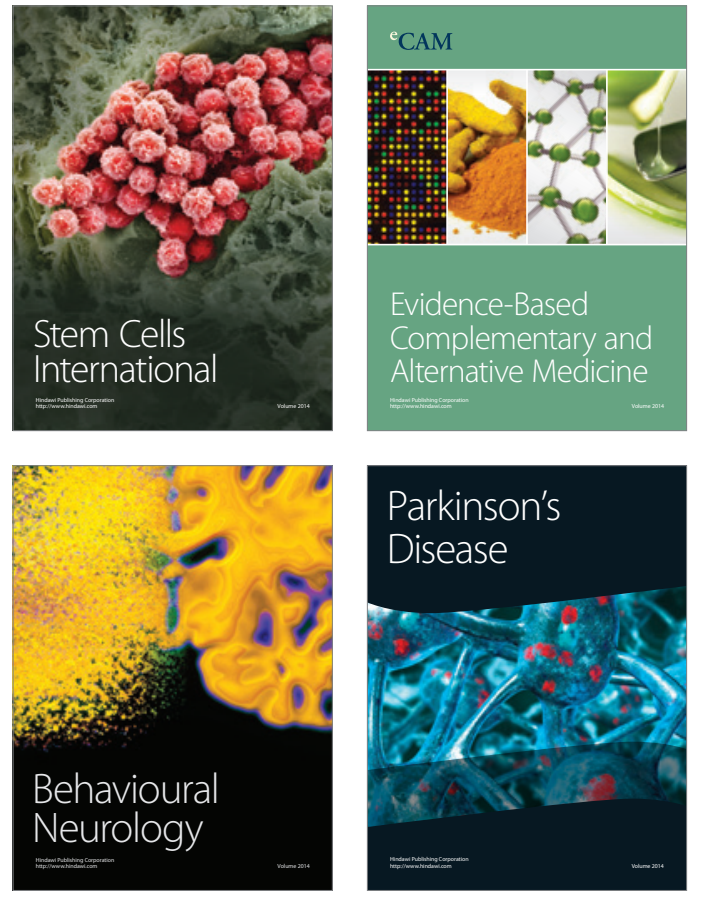
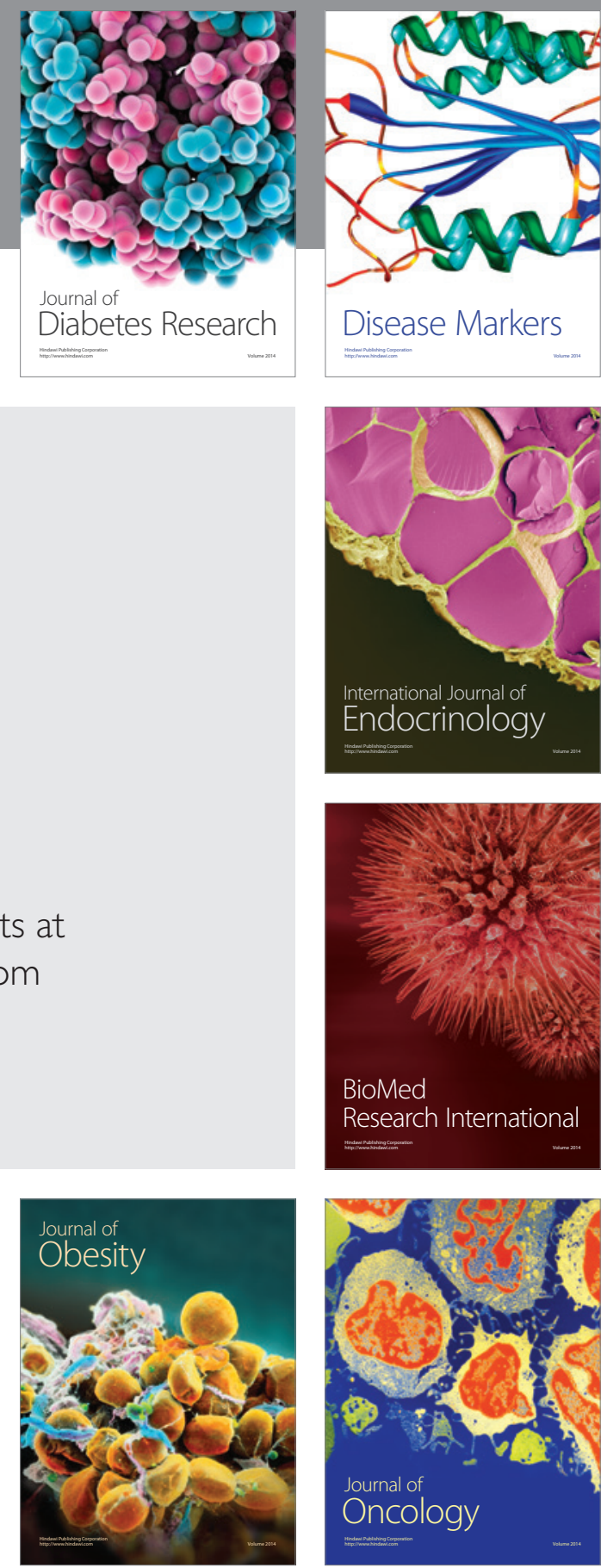

Disease Markers
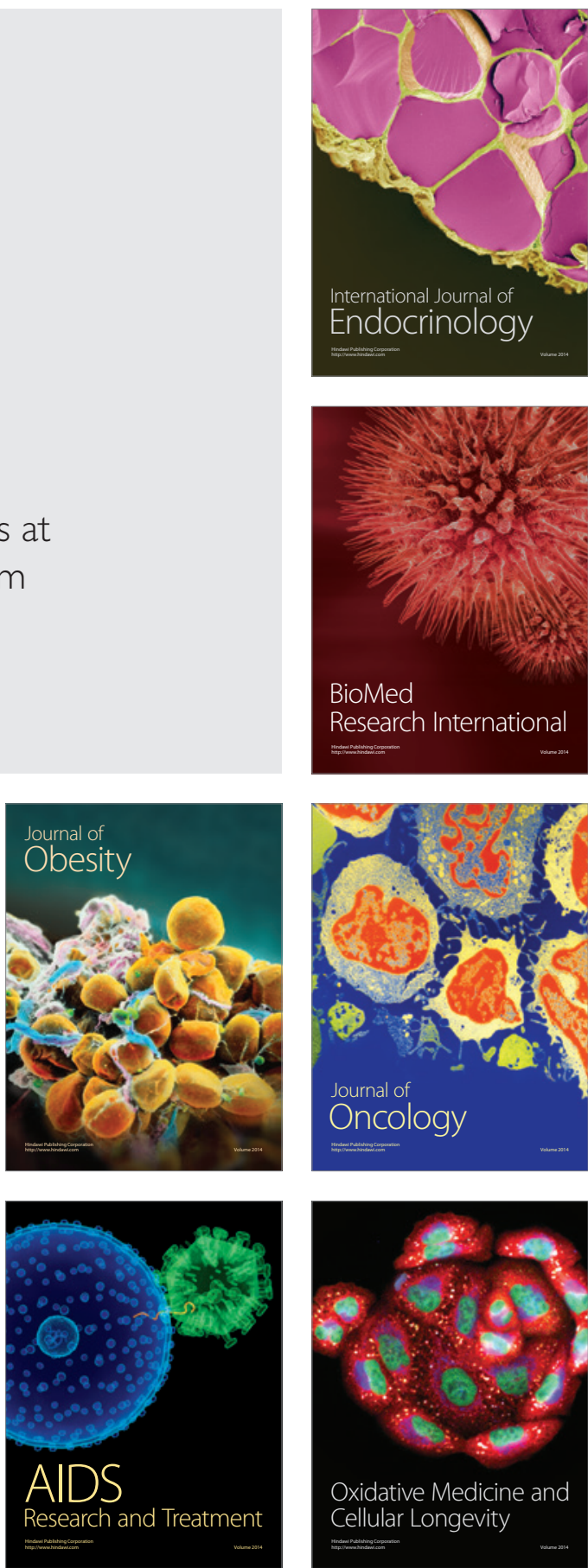